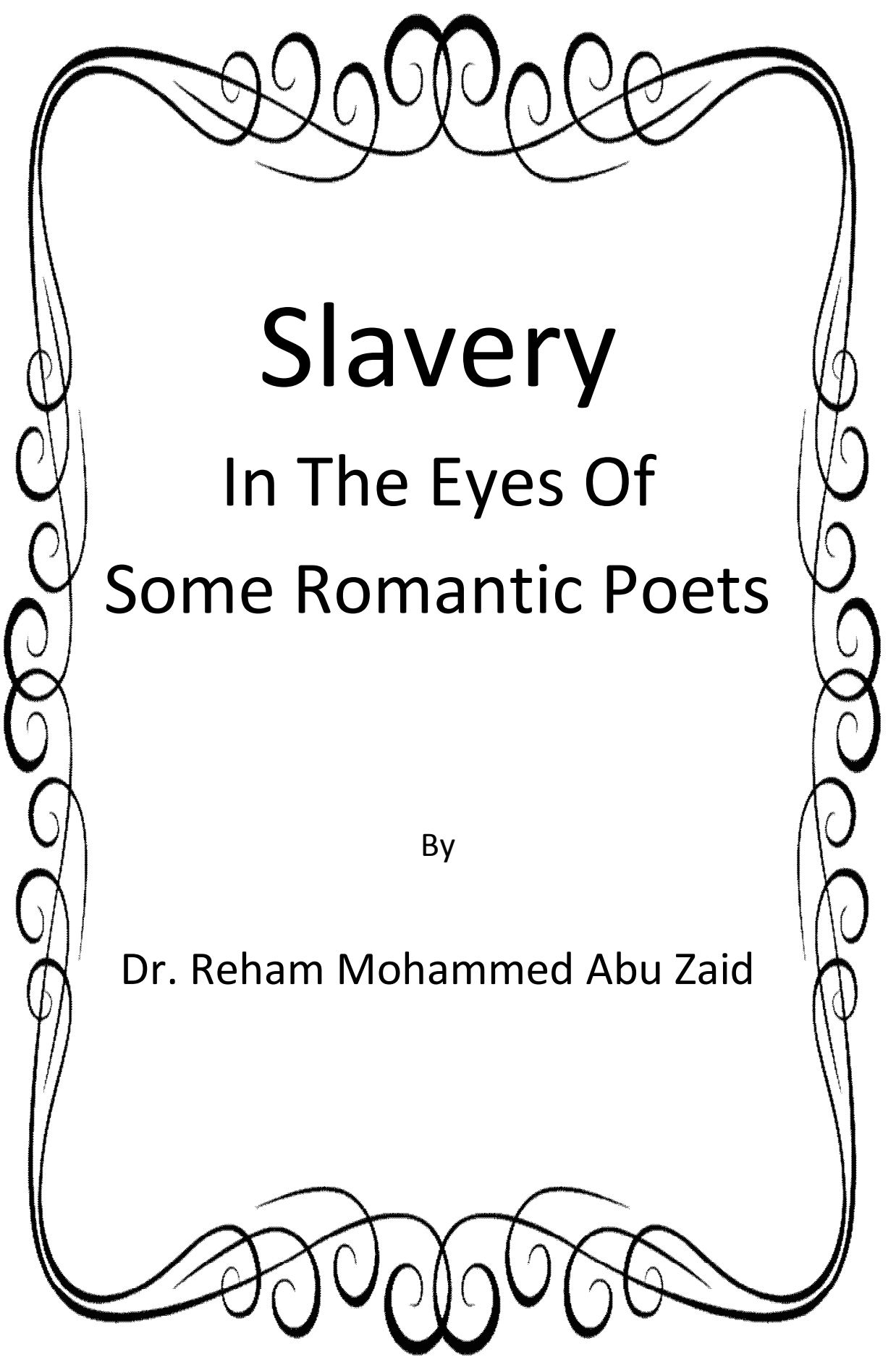


Historia, memoria y mito en Beatus Ille de Slavery In The Eyes Of Some
Dra Reham Mohammed Abu Zaid 


\section{Slavery in the Eyes of Some Romantic Poets}

The Romantic poets discarded the lords and fops of their society and turned the full force of their humanitarianism to the simple humble people. Inspired by the principles of 'Liberty, Fraternity and Equality' of the French Revolution (1789), many Romantic poets argued for more than this, "for equal rights for black people and for women" (Ruston, 1). Romantic abolitionist poetry spurred on by and contributed to the Abolitionist Movement during the second half of the $18^{\text {th }}$ century; although slavery was not abolished completely until the end of the Romanticism. The nineteenth century was marked by a number of Reform Acts, as revolts and protests against the repressive working system in industries increased. But the reforms were not easily fulfilled, each Act, that was passed, was preceded by bitter experience of those who had to wage painful struggles and bear the unspeakable consequences. Reform Acts were passed "in the teeth of fierce resistance" either from the lords or the workers, throwing the society in great turmoil. Among the important Acts were: Abolition of the Slave Trade in 1807, Emancipation Act of 1833, Poor Law Amendment Act of 1834, and Factory Act of 1837 ...etc. In their poetry, the poets patronizingly depicted Africans as noble and uncorrupted by European civilization and employed images of the suffering of the slaves for sentimental 
effect. Yet, Romantic poets differ from each other in their situations towards this humane problem; some supported it and others ignored it. Romantic poetry was characterized by:

A disjunction in the representations of Blacks, employing the stereotype of the

'Noble Negro' as well as depicting docilely suffering slaves. There were of

course important ideological differences between the various Romantic poets,

Blake, for instance, was a strong critic of colonialist ideology whereas

Wordsworth was reluctant to join the abolitionist cause...

\section{(http://www.irank.org/cultures/pages)}

Anti-slavery English Romantic poets followed four strategies in order to abolish slavery as this research tries to trace. The effect of these strategies could be felt in England as well as in other countries. Firstly, some poets tried to state the immorality of slavery. They posed the question of how can a human being be enslaved by another human being. It is an immoral matter because God created all human beings equal. William Blake's poem, "The Little Black Boy" is discussed here as an example. Secondly, some poets condemned the slave trade showing the atrocity and the inhumanity of it. 
Robert Southey's poem, "The Sailor Who Had Served in the Slave Trade" draws a hateful picture to the traders and the trade itself, depicting it as a sin. Thirdly, some poets called for boycotting the slaves' products as a means of dispensing with the slaves themselves, among these poets, William Cowper was prominent. His poem, "Pity for Poor Africans" achieved a great fame and had a great effect on the English society. Fourthly, some poets directed their poems to criticize severely the status and the inhuman conditions of the slaves' lives. These poets presented how slaves were treated inhumanely and lived in the most awful conditions. Hannah More's poem, "Slavery, a Poem" is a good example proposing terrifying pictures of their conditions. A thematic study of these poems is presented, though technique is never ignored. Some quoted verses may be long, but this may be excused as they present together a complete idea and draw a perfect picture. Important key words are underlined in order to attract attention to them and stress the main ideas.

Firstly, William Blake (1757-1827) was greatly inspired by the concepts of freedom and individuality that began to spread in Britain after the French Revolution. He was an important figure in the British Abolitionist Movement, and one of its leaders. Slavery appears as a recurrent theme in his art and writings. In his collection Songs of Innocence (1789), there are anti-slavery hints here and there. This collection is "considered a beacon of truth to the world of slavery" (http://thehottestpeoplein turnersclass). One of the poems of this collection, "The Little Black Boy" (1788), is directly an anti-slavery poem. 
It has definite abolition tones. In this poem, Blake discusses the immorality of slavery. He presents a Biblical point that 'man was created in the image of God'. God did not create Blacks to be enslaved by White people. On the contrary, the Blacks may be nearer to the mercy of God than the White.

Blake's poem, "The Little Black Boy" dates from the dawn of the Anti-slavery Movement in England, just a year after the Society for the Abolition of the slave trade (1787) had been founded. The two main characters of the poem are a little Black boy and a little White boy. The power-shift between the Black boy and the White boy is considered its key feature. The little Black boy is the narrator of the poem. He says in the opening lines of the poem:

My mother bore me in the southern wild,

And I am black, but O! My soul is white;

White as an angel is the English child,

But I am black as if bereav'd of light.

(McGann, 59)

The little Black boy, as the main character and the speaker of the poem, clarifies that though his exterior is black, his soul is white, or you can say pure, like the angelic looking English child. The hyperbaton of the third line helps the Black boy to confine the 'angelic soul' to the White boy, showing his internal feelings of inferiority. Moreover, the words of the little Black boy reflect his feelings of his physical inferiority to his white counterpart. The English child is white like "an angel", 
while the Black boy appears "as if bereav'd of light". He mourns his own state: "and I am black, but O!" The simile in the third line likens the White boy to "an angel" showing his superiority. The poet plays upon the traditional stereotypes of 'black' and 'white', 'black' is the color that denotes evil and sin, and 'white' is the color that denotes innocence and purity. But he reveals, then, other interpretations to this denotation. The little Black boy completes saying that:

My mother taught me underneath a tree,

And sitting down before the heat of day,

She took me on her lap and kissed me,

And pointing to the East began to say:

Because of his tormenting feelings, the little Black boy goes to his mother who in turn tries to soothe him kindly. In the second line of this second stanza, "the heat of day" is a metonymy for the sun. The mother points to the East where 'sun' rises saying that:

"Look on the rising sun: there God does live

And gives his light, and gives his heat away.

And flowers and trees and beasts and men receive

Comfort in morning, joy in the noonday.

And we are put on earth a little space,

That we may learn to bear the beams of love,

And these black bodies and this sun-burnt face

Is but a cloud, and like a shady grove. 
For when our souls have learn'd the heat to bear

The cloud will vanish we shall hear his voice.

Saying: 'Come out from the grove, my love \& care,

And round my tent like golden lambs rejoice.' "

The little Black boy's mother teaches him that this life is only a period of trial and preparation, in which we learn to bear the "beams of love" emanating from the sun where "God does live". The poet uses the sun as a metaphor for God and his kingdom. In God's kingdom, both the Black boy and the White boy will play around God's tent like innocent lambs. This happens only when they become equal to each other: "For when our souls have learn'd the heat to bear". The Black boy will become like the White boy, who in turn will learn to love his Black counterpart. The sun where "God does live" (the third stanza), is the source of "comfort in morning" and "joy in noonday". Where does the sun rise and where this comfort and joy take place? This happens in the East, in Africa. All the creatures receive the beams of the sun which rises in Africa. These beams are "beams of love" (the fourth stanza). The two metaphors, "gives his light" and "gives his heat away", liken the 'light' and the 'heat' to physical substances which all creatures receive. But Black people receive more "beams of love" than White people. The poet mentions "black bodies" and "sun-burnt face" to imply that Black people are near to God as a result of their suffering; for one can only become dark and sunburned as a result of being exposed to sun's rays. Hence, the paleness of the English boy is symbolic of the fact that the English are distanced from God as a result of 
their treatment of the Black people. The metaphor in the last line of the fourth stanza sets an implicit comparison between the black color and the 'cloud'. Then the poet completes the idea with an explicit comparison in the following simile that the black color is as "a shady grove". The poet wants to send a message to the readers that it is immoral to appreciate people by their external color, which is ephemeral. The purity of their souls is the only criterion. The poem is completed as the following:

Thus did my mother say, and kissed me;

And thus say I to little English boy.

When I from black and he from white cloud free,

And round the tent of God like lambs we joy:

I'll shade him from the heat till he can bear,

To lean in joy upon our father's knee.

And then I'll stand and stroke his silver hair,

And be like him, and he will then love me.

(McGann, 59-60)

The little Black boy states that: his dark skin actually has the positive effect of enabling him to get closer to "the light" and "heat" of God's love. Once in God's kingdom, the Black boy (who can stand unsupported) will be stronger than the White boy (who will have "to lean in joy upon our father's knee").Yet, the Black boy will not take revenge from the White boy. He will show compassion to the White boy by "shading him from the heat" and "stroking his silver hair". The little Black boy does not have enough experience to understand why 
inequality exists; this is why his story is among The Songs of Innocence. The poet, William Blake, suggests that in God's kingdom, color is irrelevant. Both 'white' and 'black' skins are described as "clouds" that interfere with the sun's rays (God's love); dulling the people's perception of the things that all races have in common, that is our shared humanity. Why shouldn't all people love each other regardless of race or skin color?

The idea of the importance of soul purity is completed in the similes of the last lines of the fifth and sixth stanzas, "like golden lambs rejoice" and "like lambs we joy". The 'lamb' is a traditional symbol of innocence and soul purity. After getting of the "clouds" of colors, both the Black and White boys are the same. They are like 'innocent lambs': "And then I'll stand and stroke his silver hair, / And be like him, and he will then love me."

Blake's poem, "The Little Black Boy", consists of seven quatrains in which the first and the third lines are rhymed together and so are the second and the fourth. Hence, the rhyme scheme is: abab cdcd efef ghgh---etc. This regular rhyme scheme is suitable for the regularity of the universe and the order of God's creations. The poem contains many images and figures of speech in order to enhance the picture and clarify the poet's aim.

William Blake's poem, "The Little Black Boy" is "very persuasive" and "tastefully done". Blake "turned people against slavery through his writing and art" (Gallant, 123). The poet drew two pictures with the manuscript of the poem. One of them shows the little Black boy with his mother under a willow tree, which "symbolizes dreams, 
life and healing". Blake wants to say that "even though the fate of this boy is inevitable, there is still hope for abolitionism" (http://theworksofwb). There is another picture that shows the two little boys, the Black and the White, near a savior figure. The little White boy is kneeling in a slave-like posture and the Black boy is standing, tending to smooth the hair of the White boy. The savior focuses all attention on the White boy, excluding the Black boy, as if Blake wants to say to the English people that: the slave is the White boy not the Black boy, he is sinful because of not loving the Black boy. William Blake left the reader with a message of a lasting effect. He declares the equality of all men and the immorality of slavery. His most dangerous and significant weapon in his fight to end slavery was his pen and his palette. The effects of his works remained widespread in the years to follow. His works contributed to the success of abolitionism not only in Britain but also in America.

Beside Blake, other Romantic poets tried to follow another way of abolitionism that is condemning the slave trade. They showed the atrocity and the inhumanity of the slave trade and how the slaves were treated violently; subjected to death easily during this trade. Their poems produced abominable pictures. Robert Southey (1774-1843) was poet laureate of England for nearly 35 years. However, Southey belonged to a good family and was educated at Oxford and Balliol; the humble people and the slaves were one of his most important priorities. In his powerful expressive dramatic poem, "The Sailor Who Had Served in the Slave Trade" (1798), Southey presents the horrors of the slave trade. 
The poem's two main characters: (1) the Sailor who symbolizes the slave trade/ traders and (2) a Stranger who symbolizes the audience or the English people, and two minor characters: (1) the Captain who symbolizes the savage people who encourage the slave trade and deal with the slaves with atrocity and (2) a slave woman who symbolizes the slaves and their suffering. This dramatic poem unfolds the details of a story about the slave trade narrated by the Sailor to the Stranger in a building way. The poet aims to put the English people into action; they should end the slave trade as soon as possible. The poem begins with an anguished miserable Sailor on his knees praying in a hovel. A Stranger hears his groaning and praying. When the Stranger encounters him asking him about the cause of his despair, the Sailor confesses that he cannot find rest because of a wicked thing he has done:

He stopt, - it surely was a groan

That from the hovel came!

He stopt and listened anxiously

Again it sounds the same.

It surely from the hovel comes!

And now he hastens there,

And thence he hears the name of Christ

Amidst a broken prayer.

(Southey: 1799, 110-113) 
Southey attracts the readers' attention creating a vague suspense. The story of the poem starts with an unknown person hearing a groan of another unknown person. He listens "anxiously"; this adverb increases the tension of the verses. He becomes sure, so he hurries up towards the hovel. The anonymity of the persons gives generality and mystery. The poet casts ambiguous questions. Who are these two persons? What is the story of the man who lives in the hovel? Why does he live there alone? Why does he groan? Why does he call the Christ in "a broken prayer"? The poet completes his recitation saying:

He entered in the hovel now,

A sailor there he sees,

His hands were lifted up to Heaven

And he was on his knees.

Nor did the Sailor so intent

His entering footsteps heed,

But now the Lord's Prayer said, and now

His half-forgotten creed.

And often on his Saviour call'd

With many a better groan,

In such heart-anguish as could spring

From deepest guilt alone. 
He ask'd the miserable man

Why he was kneeling there,

And what the crime had been that caus'd

The anguish of his prayer.

(Southey: 1799, 107-108)

The Stranger finds a sailor in a state of humiliation and regret asking for God's forgiveness. He doesn't notice the Stranger's footsteps and indulges himself more and more in his prayers: "And often on his Saviour call'd / With many a better groan" (L.17 - 18). The Stranger suspects that this Sailor has committed a sin. The poet presents in these above lines the state of the Sailor when the Stranger finds him: "A Sailor there he sees" (L.10) / "Nor did the Sailor so intent" (L.13) / "And what the crime had been that caus'd" (L.23). Southey also uses effective words to attract the attention of the reader depicting the Sailor's state such as: "groan", "anxiously", "broken prayer", "bitter groan", "heart-anguish", "miserable" and "anguish". The poet tries to prepare the reader to the Sailor's recitation to his sin by these introductory lines. The Sailor suffers from something that he has done, he wants to be penitent, but he cannot. Upon asking him about his crime that has caused all this anguish, the Sailor replies:

Oh I have done a wicked thing!

It haunts me night and day,

And I have sought this lonely place

Here undisturb'd to pray. 
I have no place to pray on board

So I came here alone,

That I might freely kneel and pray,

And call on Christ and groan.

The Sailor confesses that he has committed a crime that haunts him day and night. He wants to be penitent, so he keeps praying lonely here in this isolated hovel. He can't pray on board because it is the place in which he has committed his crime. The memory of his shameful deed haunts him there and chases him from place to place, he recites the following:

If to the main-mast head I go,

The wicked one is there,

From place to place, from rope to rope,

He follows every where.

I shut my eyes,- it matters not -

Still still the same I see,-

And when I lie me down at night

'Tis always day with me. 
He follows follows every where,

And every place is Hell!

O God - and I must go with him

In endless fire to dwell.

He follows follows every where,

He's still above - below,

Oh tell me where to fly from him!

Oh tell me where to go!

The poet uses repetition to prove that the slave trade is a sin. He repeats the same meaning over and over again through the above stanzas and the following two ones. Southey tries to affect the readers through this long preliminary introduction of the Sailor's "wicked thing" (his crime/sin). He shows how the Sailor lives in anguish and suffering, how he cannot sleep, how he cannot forget it and how he cannot go anywhere. His crime chases him everywhere. He also cannot pray on the board, why? Because it is the place of his crime. Repetition and words of sorrow are used to prove the Sailor's feelings. He writes all these introductory lines to show the tormenting state of the Sailor who has worked in the slave trade and to prepare the reader by increasing his suspense to hear the story of the Sailor's sinful action that caused him all this anguish. In the following two stanzas, the Stranger keeps asking the Sailor about his crime and the Sailors repeats the same words expressing 
his anguish. The stranger tries to soothe the Sailor, but in vain. There is a hidden warning to those who work in the same trade. The Sailor tells the story as the following:

I sail'd on board a Guinea-man

And to the slave-coast went;

Would that the sea had swallowed me

When I was innocent!

And we took in our cargo there,

Three hundred negroe slaves,

And we sail'd homeward merrily

Over the ocean waves.

In L. 57, Southey, after a long effective introduction, that prepares the reader to accept that the slave trade is a sinful act, begins to tell in details the atrocious process of bringing the slaves from Africa. It is known that Britain was a leader in the Atlantic slave trade. Most of the slaves were transported from Africa to the Americas and never saw the British Isles. Those who came to Britain worked as household servants. By the $18^{\text {th }}$ century, the slave trade became a major economic mainstay for such cities as Bristol and Liverpool, engaged in the so-called 'Triangular Trade'. The ships loaded with goods and set out from England to the West African shores and came back loaded with slaves through the infamous 'Middle Passage' across the Atlantic and then were sold at 
considerable profit for labor in plantations. The ships returned to England loaded with the products of slave labor, such as sugar, cotton and rum, in order to sell them. Despite this financial profit, some people condemned slavery and an anti-slavery movement arose. Southey wrote this anti-slavery poem to attack this trade, in spite of its financial gains. Because of these financial gains, the crew "sail'd homeward merrily" after having 3 hundred slaves. Yet, the main character of the poem confesses that he has been "innocent" before bringing those African slaves, and wishes that he would drown in the sea before sharing in this sinful act (L.59). The Sailor completes increasing the tension and escalating the events of the story towards its climax as the following:

But some were sulky of the slaves

And would not touch their meat,

So therefore we were forced by threats

And blows to make them eat.

68

One woman sulkier than the rest

Would still refuse her food, -

O Jesus God! I hear her cries -

I see her in her blood! 
The Captain made me tie her up

And flog while he stood by,

And then he curs'd me if I staid

My hand to hear her cry.

She groan'd, she shriek'd -I could not spare

For the Captain he stood by -

Dear God! That I might rest one night

From that poor woman's cry!

80

She twisted from the blows -her blood

Her mangled flesh I see -

And still the Captain would not spare -

Oh he was worse than me!

She could not be more glad than I

When she was taken down,

A blessed minute - 'twas the last

That I have ever known!

I did not close my eyes all night,

Thinking what I had done;

I heard her groans and they grew faint

About the rising sun. 
She groan'd and groan'd, but her groans grew

Fainter at morning tide,

Fainter and fainter still they came

Till at the noon she died.

The Sailor tells that some of the African slaves have refused to eat, but by threat and beat they have eaten. Then, the Sailor focuses on one of them: a slave woman who has continued to refuse to eat. The Captain has forced him to beat her severely, though he has not wanted to do this. He has heard her groans and suffering all night long till she died the next day: "She rested from her pain" (L.98). They threw her in the sea: "I saw the sea close over her, / Yet she was still in sight" (L. 101 -2). The Sailor is and will be eternally haunted by the image of this wronged woman, he wonders: "Shall I have rest again?!" He prays for comfort, mercy and forgiveness: "Dear Christ have mercy on my soul, / O God deliver me!" (L.107 - 8). He wishes not to sail again on a slave trade ship in order not to "Commit that sin no more" (L.112). He insists that he is now "lost" and asks the Stranger what he can do: " O give me comfort if you can -/ Oh tell me where to fly -/ And bid me hope, if there be hope," (L.113 -15). The Stranger replies sadly and helplessly that the only way out is the way of God, the Sailor should repent and seek God's forgiveness. He says the following: 
Poor wretch, the Stranger he replied,

Put thou thy trust in heaven,

And call on him for whose dear sake

All sins shall be forgiven.

This night at least is thine, go thou

And seek the house of prayer,

There shalt thou hear the word of God

And He will help thee there!

(Southey: 1799, 113-114)

Southey's above poem depicts the slave trade in an abominable picture full of wrongness, cruelty and tyranny. Both the images and the religious vocabularies support this depiction leaving the English society with a message that true Christianity does not forgive the existence of slavery. The slaves should be liberated. Some examples of the religious vocabularies are: "Christ" (L.1), "prayer" (L.8 \& 24), "Heaven" (L.11 \& 118), "Lord's prayer" (L.15), "Saviour" (L.17), "pray" (L.28, 29 \& 31), "Hell" (L.42), "Fire" (L.44), "sin" (L.52 \&112), "cursed deed" (L. 53), "innocent" (L.60), "O Jesus God" (L.71), " Dear God" (L.79), "O Christ, O blessed God" (L. 99), " Dear Christ" (L.107), "O God" (L.108), "sins" (L.120), "the house of prayer" (L.122) and "the word of God" (L.123). The poet uses some technical devices such as alliteration, assonance; consonance and scattered rhyme here and 
there in order to create a sad musical effect accompanying the Sailor's mood and the escalation of the events. The poet also uses other poetic techniques to attract the attention of the reader and clarify the intended meaning as hyperbaton, caesura, repetition...etc.

Southey uses in "The Sailor Who Had Served in the Slave Trade" his masterly ability as a talented poet to invoke change in the English society and to put an end to the slave trade through the effect of religion. In addition to using religious vocabularies, the poet likens the slave woman to 'Jesus Christ' Himself: (1) like Christ, she is beaten, (2) like Christ she is made to bleed and (3) like Christ, she is made a public spectacle. Southey's effective Christian imagery is inescapable. Firstly, just as Christ was beaten for no fault of His own, so is the woman. Secondly, like Christ's torment and agony, "she groan'd, she shriek'd" and "she twisted from the blows - her blood\Her mangled flesh I see" (L.77-78 \& 81-82). Southey points to the woman's blood over and over again in the poem. He wants to say that upon this blood the English empire and its wealth have been built. This blood stains the whole English society with sins. No one in the English society is far from these sins. All the English people are sinful; they share in the slave trade whether directly or indirectly (by keeping slaves in their houses or even by using slave products as sugar, rum, cotton, coffee and tobacco). The third similarity between the slave woman and the Christ is that "she was taken down" 
(L.86). She was made a public example like Christ. These similarities show the slaves in general (as represented by this woman) as better than the sinful English people. Consequently, the readers can imagine the Captain who encourages the slave trade and urges the Sailor to flog the helpless slave woman as the Devil.

Yet, the Sailor realizes the enormity of his sin. He wishes that he would die before doing this sin. He now hopelessly calls for repentance: "O give me comfort if you can-/ Oh tell me where to fly -/ And bid me hope, if there be hope / For one so lost as I" (L.113-116). Though he did not intend to commit this sin of flogging the poor slave woman and killing her, he realizes that he has the blood of an innocent person on his hands. He knows that he is guilty by sharing in the slave trade: "tomorrow I set sail again \Not to the Negroe shore\ Wretch that I am I will at least \Commit that sin no more" (L.109-112). The runon-line technique and enjambment help the narrator to recite his story quickly and help the readers to follow him in a way full of suspense and sympathy. Southey succeeds in putting the English society face-to-face with his sin that is slavery and the slave trade. This sinful society should repent and stop this trade and act against the indecencies and injustices towards slaves; "go thoul and seek the house of prayer $\backslash$ There shalt thou hear the word of God \And He will help thee there" (L.121-124).

Boycotting the products of the slave labor was a third strategy of some Romantic poets for abolition. After 
losing colonies in America, Britain still held colonies in Asia and Africa which were important for trade. Importing black slaves, mainly from Africa to work on the British-owned sugar plantations in the Caribbean was a crucial factor in the trading power and immense wealth of the British Empire. The slaves were brought and kept for hard work on the farms. They were suffering in this strenuous work; they were beaten, flogged and burnt. Many of them died because of the inhuman circumstances in which they were living. To boycott the goods produced by them, means to condemn and to end slavery, as thought by some Romantic poets. One of these Romantic poets was William Cowper.

William Cowper (1731-1800) wrote poems that "gave voice to humanitarian concern" such as The Task, in which he laments India's sufferings under Warren Hastings. Cowper uses heroic couplets as well as blank verse "with equal felicity and virtuosity" to serve his poetic goals (Rajimwale, 248). He wrote successfuly a number of anti-slavery poems. His close friend, the antislavery campaigner John Newton, asked him to write frequently in support of the abolitionist campaign. Cowper wrote several well-known poems on slavery in the 1780s, "many of which attacked the idea that slavery was economically viable" (http://www.bl.uk/learning). Cowper's poem, "Pity for poor Africans", was written in 1788, calling directly for boycotting the slave products. It is a poignant story of a man, and more importantly a society that knows slavery is wrong, yet doesn't want to 
give up any of its benefits. Cowper writes the first stanza as the following:

I own I am shock'd at the purchase of slaves,

And fear those who buy them and sell them are knaves;

What I hear of their hardships, their tortures, and groans

Is almost enough to draw pity from stones.

(Cowper: 1830, 244)

Cowper's poem, "Pity for Poor Africans", was "printed on good quality paper by the Society for the Abolition of the Slave Trade and distributed to thousands with the subscription 'A subject for conversation at the tea table' " (Midgley, 143). This publication was evidently targeted at the middle-class housewife, who, as the Abolitionists believed, sets the domestic agenda and controlled the purchase of slave-grown products like tea, coffee, sugar...etc. This was one of the tactics of a multi-facetted campaign (Midgley, 143).

The title of the poem "Pity for Poor Africans" draws sympathy of the readers. It indicates how it is an antislavery poem and how the African slaves are poor and deserve pity. In the first stanza the poet shows that he is shocked because of the slave trade: "I own I am shock'd 
at the purchase of slaves". The poet uses old terms as: "I own" meaning "I admit" and "knaves" meaning "rascals". This old usage may refer to the long period of buying and selling human beings (slavery) from ancient times till the time of writing this poem. So, the slave trade should be ended. The poet describes those who buy and sell slaves as 'rascals'. He, then, states that the suffering, torture, pain and groan of the slaves are enough "to draw pity from stones". He hints that the hearts of those who keep slaves are worse and harder than stones. They wrong and torture those poor slaves without feeling, mercy or regret. The poet completes the following stanzas after the above one, shifting his feelings in a shocking way, he writes that:

I pity them greatly, but I must be mum,

For how could we do without sugar and rum?

Especially sugar, so needful to see?

What? Give up our desserts, our coffee, and tea!

Besides, if we do, the French, Dutch, and Danes,

Will heartily thank us, no doubt, for our pains;

If we do not buy the poor creatures, they will,

And tortures and groans will be multiplied still.

In the second stanza, of Cowper's poem, the proposed questions present the views of the merchants and planters who have warned that abolition would ruin Britain as the whole economy would collapse. Cowper also criticizes "those seeming liberals who expressed 
sympathy for the enslaved Africans but always concurred in finding excuses to slow down the movement for abolition" (http://www.thefreelibrary.com). Consequently, the shift of the poet's feelings and words intends to attack those hypocrite people in an ironic way. He presents their false pretensions that they sympathize with the slaves but they can not live without the products of the slave labors.

In the third stanza, Cowper suggests that if Britain did not engage in slavery, its commercial rivals (the French, the Dutch and the Danes) would soon fill the gap and the Africans would be in a much worse situation: "And tortures and groans will be multiplied still". He asks ironically in the fourth stanza, which completes the idea of the preceding two (the second and the third): "But, while they get riches by purchasing blacks, / Pray tell me why we may not also go snacks?" The poet, here, discloses the inhumanity of the whole materialistic Western world. He moves to tell an allegorical story in the following stanzas to undermine the false pretensions of those who defend slavery: "Your scruples and arguments bring to my mind / A story so pat, you may think it is coin'd". He prepares the reader in these lines of the fifth stanza and tries to convince him by its reality. Then, he begins his recitation in the sixth stanza, he writes the following:

A youngster at school, more sedate than the rest, 
Had once his integrity put to the test;

His comrades had plotted an orchard to rob,

And ask'd him to go and assist in the job.

He was shock'd, sir, like you, and answer'd - "Oh, no

What! Rob our good neighbour! I pray you don't go;

Besides, the man's poor, his orchard's his bread, Then think of his children, for they must be fed."

"You speak very fine, and you look very grave,

But apples we want, and apples we'll have;

If you will go with us, you shall have a share,

If not, you shall have neither apple nor pear."

They spoke, and Tom ponder'd - ! "I see they will go:

Poor man! What a pity to injuro him so!

Poor man! I would save him his fruit if I could,

But staying behind will do him no good.

If the matter depended alone upon me,

His apples might hang till they dropt from the tree; 
But since they will take them, I think I'll go too,

He will lose none by me, though I get a few."

His scruples thus silenc'd, Tom felt more at ease,

And went with his comrades the apples to seize;

He blam'd and protested, but join'd in the plan;

He shar'd in the plunder, but pitied the man.

(Cowper: 1830, 244-246)

Cowper uses a deep effective symbolic story to criticize slavery and those who are involved in it. He presents their views; 'why we stop slavery, though we have pity for poor Africans, and others would benefit from it'. Africans may enslave each other, may capture each other in wars, may execute each other and may be enslaved and tortured by other European people, so capturing them in Britain is much better for them and for Britain, as they think. Cowper compares those who are involved in slavery symbolically to a bunch of schoolboys who think to steal apples from a poor peasant farmer. One "youngster" is unsure and has pity for his neighbor, but he sees that he should have his share which will not harm the peasant as all his friends will take a bigger one, yet it will have benefit for him. The used symbols are very clear: the poor neighbor peasant is Africa, the apples symbolizes the enslaved Africans, the school boys symbolize the Western countries and those who have slavery and capture slaves and the youngster symbolizes those who have pity for slaves but want to benefit of 
them economically saying false excuses to explain and defend their immoral deeds; as the slave products achieve great financial gains for them. The important key words in the poem are underlined in order to clarify the intended meaning and the hidden message.

The abolitionist campaigners used Cowper's above poem and other means for boycotting the slave products as mottoes, signs, inscriptions, drawings and others. They saw that if an economic pressure could be put on slavedependent industries (rum, cotton, tobacco, coffee and particularly sugar) then this might hasten the end of slavery. They "brought slavery and the involvement of the domestic consumer directly into the home". A photograph of an earthenware sugar bowel with a lid and the words "East India Sugar Not Made by Slaves" inscribed on the side can be seen on the BBC History Website" (http://www.history.ac.uk 3). This campaign succeeded in achieving its aim after that, Clarkson has estimated in his book that "some 300,000 people of all ranks and parties, rich and poor abandoned slaveproduced sugar. Instead they bought sugar produced in India, where slaves labor was not used" (Clarkson, 349).

Some Romantic poets refused the inhumanity and the atrocity with which the English society treated the slaves. Their poems condemned the status of the slaves and the conditions of their lives. This was the fourth procedure which these poets followed to put an end to slavery. Hannah More was one of these poets. Her poem, "Slavery, a Poem", is a good example. 
Hannah More (1745-1833) was born in Stapleton, Bristol. Her birthplace, Bristol (along with Liverpool and London) was one of the main British ports involved in the slave trade. Despite the fact that much of Bristol's wealth relied on this and other trades, the voice against enslaving Africans was loud and persistent. The role of many of the city dwellers was also pivotal in abolishing slavery.

Hannah More was an anti-slavery campaigner. She was a friend of William Wilberforce (1759-1833) who was the main figure in the Parliament for the Abolitionist campaign, Because of his efforts, the Abolition of the Slave Trade Act was passed in 1807, abolishing trade in slavery and heavily fining those who continued to trade in slavery. She was also a friend of Thomas Clarkson (1760-1846) who was an active anti-slavery campaigner. More spoke out against slavery and joined the campaign of boycotting the slave-produced sugar in 1778. She was also the most influential female member of the Society for Effecting the Abolition of the African Slave Trade (founded in 1787). She and Ann Yearsley were among the diverse range of female poets who wrote against slavery. Hannah More was educated at Bristol where she began to publish her writings in 1760s, while she was still a teenager. Her first play, The Inflexible Captive, was staged at Bath in 1775. In 1780, she was given a copy of the former slave captain Rev. John Newton's published 
letters, which had a profound impact on her life and her anti-slavery writings (http://www.bbc.co.uk/bristol).

Hannah More's "Slavery, a Poem" was published in London in 1788. It appeared in a single British edition. Editions appeared in New York and Philadelphia later in the same year. Over the coming years, both the whole poem and extracts appeared in many anthologies. This poem has 294 lines with variations in line-length and rhyme-scheme. The poet uses many poetic devices to achieve her aim such as: powerful images, personifications, symbols, rhetorical questions, mythological references, poetic license (such as eliminating verbs or some letters from the words or violating sentence structure), allegories, invocations and apostrophes. The poet depicts the sufferings of the slaves and the inhuman conditions of their lives. She shows portraits of their suffering in order to produce sympathy for and political action on behalf of slaves from the side of the readers. So, the readers may respond to the poet's representations of the slaves' abductions, floggings, burnings, whippings and suicides. The poet begins this humanitarian poem by wondering that:

If heaven has into being deign'd to call

Thy light, O LIBERTY! To shine on all;

Bright intellectual Sun! Why does thy ray

To earth distribute only partial day? 
Since no resisting cause from spirit flows

Thy penetrating essence to oppose;

No obstacles by Nature's hand imprest,

Thy subtle and ethereal beams arrest;

Nor motion's laws can speed thy active course,

Nor strong repulsion's pow'rs obstruct thy force; 10

Since there is no convexity in MIND,

Why are thy genial beams to parts confin'd?

(More: 1788, 2)

The title of Hannah More's poem, "Slavery, a Poem", declares its subject matter and gives a general perspective to slavery. The reader expects to read an abolitionist poem only. But, in fact he may find a strong profound humanitarian poem. It deals with the shameful conditions of slaves in the British society. The reader can make out easily its hidden call for freedom, brotherhood, equality, mercy and humanity. The poet investigates the power of poetry to condemn slavery by the above introductory abolitionist questions in the first stanza. She wonders in these rhetorical questions why liberty and freedom are not given for all human beings equally, regardless of their color. She states that the white color of the British people is not an advantage, and the black color of the African is not a disadvantage. Colors of human beings are valueless. Her apostrophe, "O LIBERTY" is full of anger and wondering. She completes writing: 
While the chill North with thy bright ray is blest,

Why should fall darkness half the South invest?

Was it decreed, fair Freedom! At thy birth,

That thou shou'd'st ne'er irradiate all the earth?

While Britain basks in thy full blaze of light,

Why lies sad Afric quench'd in total night?

(More: 1788, 2)

The poet wonders why there is inequality in treating some human beings. She exclaims in a rhetorical question why freedom is not fairly distributed on earth. The North, especially Britain, has its full share of freedom, while the South, especially Africa, is deprived of its share. The poet, in an elegant metaphor, likens freedom to a sun that enlightens the earth. But unfortunately, its light is unjustifiably distributed because of the wrongness of human beings to each others. After some lines, the poet calls upon not only "Liberty" and "Freedom" for inspiration, but also upon the author of Oroonoko, Aphra Behn. Oroonoko is a narration of a slave rebellion. The poet implies that her poem's political efficacy would spring from its ability to carry the emotional impact of this novel. Consequently, any understanding of the victims' sufferings depends on the power of their representation. She continues saying:

O, plaintive Southerne! Whose impassion'd strain

So oft has wak'd my languid Muse in vain! 
Now, when congenial themes her cares engage,

She burns to emulate thy glowing page;

Her failing efforts mock her fond desires,

She shares thy feelings, not partakes thy fires.

Strange pow'r of song! The strain that warms the heart

Seems the same inspiration to impart;

(More: 1788, 3-4)

The poet begins the above verses by calling " $O$, plaintive Southerne!" by which she means the author of Oroonoko. She says "Southerne" instead of 'Southerner' eliminating the letter ' $r$ '. The mythological reference "Muse", here, refers to the impact of the author of Oroonoko on the poet calling her Muse that is to say her inspiration. She states that the real sorrowful sufferings of the slaves "living anguish, and substantial woe" (L.54) inspire her more, as there are millions who suffer so much: "For millions feel what Oroonoko felt: / Fir'd by no single wrongs, the countless host/ I mourn, by rapine dragg'd from Afric's coast" (L.56 - 58). The poet then condemns the "illiberal thought" and the "proud philosophy" of the English people which prevent the black people "the sable race" (L.60) from their rights as equal human beings. They have the same ability of thinking as the English people who "rob them of the pow'rs of equal thought" (L.62). She reassures again that the color of skin is "casual" (L.64), and we should not govern the minds or spirits of people with their colors. 
She uses rhetorical questions to help her in clarifying this meaning. She states that the black people have minds, hearts and feelings as the white people; there is no difference except the exterior "casual" color. In The following lines, the poet moves sensitively from one poetic tableau to another, depicting the painful pictures of the slaves' sufferings with highly craftsmanship. She shows the ferocious state of kidnapping the slaves, cutting them from their families and their social life. She writes the following:

Whene'er to Afric's shores I turn my eyes,

Horrors of deepest, deadliest guilt arise;

I see, by more than Fancy's mirrow shewn,

The burning village, and the blazing town:

See the dire victim torn from social life,

The shrieking babe, the agonizing wife!

She, wretch forlorn! is dragg'd by hostile hands,

To distant tyrants sold, in distant lands!

(More: 1788, 6-7)

The poet describes the slaves' kidnapping as "deepest, deadliest guilt" which has "horrors" because of its ferocity. The criminals who kidnap the African victims burn their villages or towns and banish them from their homes, their families and their countries. Their children cry and their wives agonize. The women also are treated mercilessly. They are kidnapped and sold by "hostile 
hands" in "distant lands" leaving their children. The word "dragg'd" shows the cruelty of those criminals. The slaves are kidnapped by "hostile" people and sold to "tyrant" ones. They are miserable. The result of this kidnapping and separation is the loss of any beneficent continuity and tradition between generations. The family relationships are torn between them. The poet expresses this idea writing the following:

Transmitted miseries, and successive chains,

The sole sad heritage her child obtains!

Ev'n this last wretched boon their foes deny, 105

To weep together, or together die.

By felon hands, by one relentless stroke,

See the fond links of feeling nature broke!

The fibres twisting round a parent's heart,

Torn from their grasp, and bleeding as they part. 110

Hold, murderers, hold! Not aggravate distress;

Respect the passions you yourselves possess.

(More: 1788, 7)

These above lines approve that women poets are highly qualified to show sensitively home and family feelings; "feminine Romanticism...celebrates the domestic affections, family and social bonds" (Ruston, 3). The poet here links her political critique of slavery to the institution of domesticity. Her depiction of the maternal separation engenders the slaves' suffering (some 
important words are underlined). The images here transmit the miserable state and feelings from the slaves to the readers. The poet moves the readers' feelings to the extent of crying. The readers abhor slavery and all who have shared in it. She shows how the woman slave and her baby have the same miserable fate. He will inherent nothing, except the same "chains". The kidnappers prevent them from every right as human beings even from the "last wretched boon" that is "to weep together, or together die". These criminals break the natural bonds between the mother and her baby. They even have no respect for these natural feelings and this agony: "The fibres twisting round a parent's heart, / Torn from their grasp, and bleeding as they part". These kidnappers are "murderers" as the poet sees them; she orders them not to "aggravate distress" and to "respect the passions" that they themselves possess. They have the same maternal and familial feelings, why they deny them for the slaves. The poet continues in the following lines completing the same meaning that the ruthless criminals enjoy the love of their "offspring" and their "native land", they have "HOME" and "FREEDOM"; why they rob them from the slaves. The capitalization of all the letters of these two words adds a more emphasis on the intended meaning. She presents the causes of their sinful actions towards the slaves. They are fortune hunters searching for the financial gains regardless of human principles: "Gold, better gain'd, by what their ripening sky, / Their fertile fields, their arts and mines supply. / What wrongs, what injuries does Oppression plead / To smooth the horror of th' unnatural deed?" The 
poet sees that it is an "unnatural deed" that man enslaves another man. She, then, moves to another tableau in which she transfers the scope to the conditions of the slaves in the English society and the English plantations. This tableau shows the wrongness from which the slaves suffer whether it is insult, thirst, hunger, hard labor, strenuous work, burning, and / or whipping. These ideas are expressed tactfully as the following:

Rhetoric or verse may point the feeling line, $\quad 165$

They do not whet sensation, but define.

Did ever slave less feel the galling chain,

When Zeno prov'd there was no ill in pain?

Their miseries philosophic quirks deride,

Slaves groan in pangs disown'd by Stoic pride. 170

When the fierce Sun darts vertical his beams,

And thirst and hunger mix their wild extremes;

When the sharp iron wounds his inmost soul,

And his strain'd eyes in burning anguish roll;

Will the parch'd negro find, ere he expire,

No pain in hunger, and no heat in fire?

For him, when fate his torture'd frame destroys,

What hope of present fame, or future joys?

(More: 1788, 10-11) 
The poet, Hannah More, shows how the slaves bear pains that all the English people cannot bear: "disown'd by Stoic pride". Mentioning "Stoic pride" here is very significant. It is related to the school of philosophy founded by Zeno about 300 B.C., holding that the wise man should be free from passion and unmoved by joy or grief. The slaves overcome the members of this school in their indifference to pain. They undergo more and more pain and suffering. They are exposed to chains, burning beams of the sun, thirst, hunger, burning by fire and flogging: "wounds his inmost soul". She presents "a complete set of chains fitted to every separate limb of these unhappy innocent men, together with instruments for wrenching open the jaws, contrived with such ingenious cruelty as would shock the humanity of an inquisitor" (http://www.brycchancarey.com 7). They feel that there is no hope in life. Suicide may be the only solution from these intolerable conditions:

No Muse, O Quashi! Shall thy deeds relate,

No statue snatch thee from oblivious fate!

For thou wast born where never gentle Muse

On Valour's grave the flow'rs of Genius strews;

And thou wast born where no recording page

Plucks the fair deed from Time's devouring rage.

Had Fortune plac'd thee on some happier coast,

Where polish'd souls heroic virtue boast,

To thee, who sought 'st a voluntary grave 
Th' uninjur'd honours of thy name to save,

Whose generous arm thy barbarous Master spar'd, Altars had smok'd, and temples had been rear'd.

The poet presents the story of the suicide of a slave called Quashi. "It is a point of honor among negroes of a high spirit to die rather than to suffer their glossy skin to bear the mark of the whip" (Ramsay, 2). Quashi had somehow offended his master, a young planter with whom he had been bred up in the endearing intimacy of a play-fellow. His services had been faithful; his attachment affectionate. The master resolved to punish him, and pursued him for that purpose. In trying to escape Quashi stumbled and fell; the master fell upon him; they wrestled long with doubtful victory; at length Quashi got uppermost, and, being firmly seated on his master's breast, he secured his legs with one hand, and with the other drew a sharp knife; then said: "Master, I have been bred up with you from a child; I have loved you as myself; in return, you have condemned me to a punishment of which I must ever have borne the marks; thus only can I avoid them ;" so saying, he drew the knife with all his strength across his own throat, and fell down dead, without a groan, on his master's body (Ramsay, 2). The poet, here, describes the Master as "barbarous", while the slave, Quashi, is honorable. He prefers death more than living a shameful life: "who sought'st a voluntary grave/ Th'uninjur'd honours of thy name to save". The poet ends her poem, thus, with a hidden call to the English society to put an end to slavery. 
Hence, the Romantic poets tried to do their best to abolish slavery. Their pens were effective weapons in their battles. It is true that they and the anti-slavery campaigners did not achieve their aims easily; it took much time and great effort from them. But, finally, slavery was abolished in England. It was not until 1833 that slavery was finally outlawed in British colonies by Slavery Abolition Act (Ruston, 12). In 1839, a successor organization to the Anti-Slavery Society was formed, the British and Foreign Anti-Slavery Society. It worked to outlaw slavery in other countries and also to pressure the government to help to enforce the suppression of the slave trade by declaring slave traders pirates and pursuing them. This organization continues today as AntiSlavery International. Today, child and adult slavery and forced labor are illegal in most countries, as well as being against international law (http:// www.en.wikipedia. org/wiki/Abolitionism).

To sum up, British Romanticism is mainly characterized by a rejection of traditional social stereotypes and by the portrayal of powerful emotions and free will, introducing new concepts of reality based on imagination and nature. It planted the ideas of individualism and sentimentalism of the past. This movement emerged as a result of social and political changes that had a great impact on the British literature. It represented intense personal expression, so artists could focus on whatever turned them on as the rights of wronged men; among them the slaves. Some Romantic poets were concerned with ending slavery. They followed four strategies to put an end to it: (1) stating the immorality of slavery, (2) 
condemning the slave trade, (3) calling for boycotting the products of the slaves, and (4) criticizing the bad status and the offensive conditions of the lives of the slaves. The poems of some Romantic poets - as William Blake, Robert Southey, William Cowper and Hannah More successively - were discussed in this research as examples.

The research tried to show the feelings of some Romantic poets towards such a sensitive human case like slavery. It presented their condemnation and their trials to put an end to it and how men and women poets shared equally in this aim. It clarified a new perspective to Romanticism, not as an imaginary flying movement, but as a social and political introspective one. Rarely, anyone thinks how significantly the Romantic writings connected to more than art and poetry. Yet the Romantic period witnessed the condemnation of slavery and the call for its abolition, so the Romantic writers especially poets had a prominent share.

However, there are indirect aims of this research other than the above ones, although it has discussed an outdated case. The first one of them is to reveal the importance and the leading role of literature, especially poetry, in the society; it may be an effective force in many crucial problems. Poetry as a condensed form of literature can be more effective than any other literary genre. Its readers do not need much time in order to make out its intended message, as it is the case with other genres. Besides, it is easier and more memorable due to its technical devices. Secondly, the research calls 
for the equality of all human beings, none is better than the other except by his qualifications and morals. Thirdly, human conscience should take care with the wronged people everywhere. Fourthly, the abuse directed from a human being to another is refused. Fifthly, racial discrimination is also refused. Freedom is a right for all human beings regardless of their color, nationality and religion. No one has the right to enslave, suppress or oppress another. Every one should accept 'the other' whatever he is and whoever he is. Fighting and abolishing the present shapes of slavery is the last aim of this research.

In his 1832 review essay on a new edition of Sir Philip Sidney's The Defence of Poetry, Henry Wadsworth Longfellow argued that:

The true glory of a nation consists not in the extent of its territory, and the pomp of its forests, the majesty of its rivers, the height of its mountains, and the beauty of its sky; but in the extent of its mental power the majesty of its intellect- the height and depth and purity of its moral nature.

(http://www.poetryfoundation.org ) 


\section{Bibliography}

Clarkson, Thomas. History of the Rise, Progress and Accomplishment of the Abolition of the African Slave Trade by the British Parliament. London: John W. Parker, West Strand, 1839.

Cowper, William. The Poetical Works of William Cowper. Volume 1. London: William Pickering, 1830.

Gallant, Christine. "Blake's Anti-slavery Designs for Songs of Innocence and of Experience" in Wordsworth Circle. Volume 39. Issue 3. New York: New York University, June 22, 2008. P.123-128.

McGann, Jerome J. The New Oxford Book of Romantic Period Verse. Oxford: University Press. 1993.

Midgley, Clare. "Slave Sugar Boycotts, Female Activism and the Domestic Base of British Anti-Slavery Culture" in Slavery and Abolition: A Journal of Slave and Post-Slave Studies. Volume 17. Issue 3. London: Frank Cass, 1996. P: 143-4.

More, Hannah. Slavery, A Poem. London: T.Cadell, 1788.

Priestley, John Boynton. Literature and Western Man. London: Readers Union, Heinemann., 1962.

Rajimwale, Sharad. A History of English Literature. New Delhi: Rama Brothers India Pvt. Ltd. 2004. 
Ramsay, James. "Essay on the Treatment and Conversion of African Slaves in the British Sugar Colonies". London: J.Philips, 1784.

Ruston, Sharon. Romanticism. London: Continuum, 2007. Southey, Robert. Poems by Robert Southey. The Second Volume. Bristol: Biggs and Cottle, 1799.

http://thehottestpeopleinturnersclass.blogspot.com http://theworksofwb.blogspot.com http://www.bbc.co.uk/bristol http://www.bl.uk/learning http://www.brycchancarey.com/slavery/morepoems.htm http://www.en.wikipedia.org/wiki/Abolitionism http://www.history.ac.uk/ihr/focus/slavery http://www.irank.org/cultures/pages/392/3-slavery.html http://www.poetryfoundation.org/bio/henrywadsworth-longfellow http://www.thefreelibrary.com 